\title{
Sykepleiere kan gjøre helsetjenesten mer miljøvennlig
}

Som sykepleier er du etisk forpliktet til å tenke bærekraftig. Hvordan kan du redusere bruken av engangsutstyr eller påvirke politiske miljømessige beslutninger?

\section{Håkon Johansen}

Medlem av Rådet for sykepleieetikk, rådgiver og spesialsykepleier

Utviklingssenter for sykehjem og hjemmetjenester i Østfold

\section{Terje Årsvoll Olsen}

Medlem av Rådet for sykepleieetikk og førstelektor

Høgskulen på Vestlandet

Klima

Dilemma

Bærekraft

Miljø

Sykepleien 2020108 (81300) (e-81300)

DOI: 10.4220/Sykepleiens.2020.81300

Klimaforandringer er en realitet. Den moderne helsetjenesten både bidrar til og blir påvirket av de globale og lokale endringene. Kloden har fått dårligere helse, og den triste ironien er at helsevesenet verden over faktisk bidrar til dårligere helse hos den største pasienten av dem alle.

Global oppvarming er vår tids største helsetrussel.

Dessverre har helsesektoren bidratt til $\varnothing \mathrm{kt}$ forbruk og forurensning gjennom sitt virke, sine bygningskonstruksjoner og sin aktivitet. 
Brasilianske sykehus bruker 10,6 prosent av den kommersielle energien, NHS i Storbritannia er ansvarlig for om lag en fjerdedel av utslippene, og i USA står helsevesenet for det største forbruket av kreftfremkallende kjemikalier (1).

\section{Hva er miljøstatus i norsk helsevesen?}

Hvordan står det til i Norge? Ifølge energi- og klimaregnskapet i Helse Bergen HF i 2017 står kategorien «Medisinsk og helse» for 47 prosent av det totale utslippet i 2014 og 45 prosent i 2015 .

Utslippene knyttet til innkjøp har $\varnothing \mathrm{kt}$ jevnt. Utslippene fra pasientbehandling har $\varnothing \mathrm{kt}$ i samme periode, og utslippene knyttet til årsverk er uforandret.

Haukeland universitetssjukehus' (HUS) største utslippskilde er innkjøp av varer og tjenester, og det er i den kategorien HUS kan gjøre store tiltak gjennom å sette spesifikke miljø- og klimakrav når de kjøper varer og tjenester.

\section{«Helsetjenesten jobber målrettet, men sykepleierne kan bidra mer.»}

Medisinske forbruksvarer har en $\varnothing$ kning på 26 prosent i utslipp fra $\varnothing \mathrm{kt}$ forbruk (2). Antakelig er disse tallene nokså like ved andre helseforetak, så vi ser at mye er ugjort også i Norge på veien mot en mer bærekraftig og miljøvennlig helsetjeneste.

Helsetjenesten jobber målrettet, men sykepleierne kan bidra mer. Derfor er det viktig å peke på de etiske forpliktelsene som ligger i å tenke bærekraftig i vårt faglige virke. Ta en runde i kollegiet og drøft bruk og kast på din avdeling.

\section{Sykehus skaper mye miljøavfall}

Miljøhelsesykepleier Gary Laustsen definerer «greening» som «behaviors or activities that improve environmental outcomes» (3). A bli grønn innebærer avfallsreduksjon og energi- og ressursbevaring. 
Miljøhelseaktivist Hollie Shaner-McRae (4)

poengterer at det er tidkrevende og viktig å skape

miljømessig bærekraftig helsetjeneste, og forklarer at sykehus skaper avfall som er noe av det mest innholdsrike og vanskelige å håndtere, uavhengig av bransje.

Fast avfall, bioavfall og farlig avfall produseres i store mengder 24/7 året rundt, vanligvis tett på mennesker som er særlig sårbare. HUS er opptatt av å bevisstgjøre sine medarbeidere gjennom en vedtatt miljøpolitikk. Rapporten om Haukeland universitetssykehus' energiog klimaregnskap er nyttig lesning (2).

\section{Sykepleiere kan påvirke direkte}

Selv Florence Nightingale hadde en streng miljømessig kontroll som en grunnpilar. Å legge pasientene i det sunneste miljøet var essensielt for helbredelse. Også i dag er sykepleiere i en unik posisjon til å forfekte forandringer og gjøre helsetjenesten miljømessig bærekraftig.

På verdensbasis representerer sykepleiere den største helsepersonellgruppen. Sykepleiere innehar i dag mange sentrale posisjoner i samfunnet. Vi har en stortingspresident, en statsråd og flere stortingsrepresentanter som er sykepleiere.

\section{«Sykepleiere innehar i dag mange sentrale posisjoner i samfunnet.»}

Det er også rikelig med politikere på lokalnivå som er sykepleiere. I tillegg finner vi sykepleiere $\mathrm{i}$

helsevesenet på direktør- og styrenivå, institusjonsnivå og avdelingsnivå, for ikke å glemme på gulvet i daglig kontakt med pasienten. 
Nightingale ville kanskje argumentere for at vi burde forvente et miljøengasjement hos sykepleierne og en bevissthet om forbruket knyttet til daglige sykepleietjenester. Helsetjenesten påvirker både pasienter og ansatte direkte innenfor veggene og befolkningen generelt utenfor med sin virksomhet.

Helsetjenesten kan dermed positivt påvirke den miljømessige helsen med å rette oppmerksomheten mot avfallshåndtering, ressursbevaring og resirkulering. Harris og medarbeidere (5) peker på at utdanningene bør bli mer opptatt av bærekraftig helsetjenestedrift.

\section{Både små og store tiltak monner}

Topf (5) hevder at fornekting, gruppetenkning, uvitenhet og diffuse ansvarsområder hindrer ansatte i å ta tak for å gjøre tjenestene grønnere. Er det forenlig med god sykepleie å være klimafornekter?

Hvordan står det til med avfallshåndteringen og resirkuleringen i spesialist- og kommunehelsetjenesten? Hva med unødig bruk av engangsutstyr? Hvor kommer utstyret fra?

\section{«Er det forenlig med god sykepleie å være klimafornekter?»}

Den etiske forpliktelsen er åpenbar, og ingen medisinsk kunnskap vil minske sykepleierens ansvar for å håndtere miljøet slik at det fremmer positive livsprosesser.

NSFs landsmøte i 2019 vedtok at sykepleiere er klare til å ta ansvar både i egen organisasjon og gjennom å Øve innflytelse på beslutninger som påvirker klimaet $\mathrm{i}$ helse- og omsorgstjenesten. Små og store tiltak kan monne. 


\section{Vi må få til en endring}

Rådet for sykepleieetikk oppfordrer til å legge press på politikere og ledere for å gjøre en kursendring med å redusere klimautslipp også i helsesektoren, i solidaritet med kommende generasjoner.

Sykepleiere må dessuten ta tak selv i sitt daglige virke. Bli bevisst på når du må bruke hansker, og når du kan la det være og heller vaske hendene. I eldreomsorgen tror vi det kan være mangel på berøring som følge av ureflektert hanskebruk.

Et berg av plastforklær kan elimineres med kunnskap og holdningsendring. Ser vi igjen til HUS som en representant for alle sykehus, og som har en vedtatt miljøpolitikk, har utslipp knyttet til medisinsk utstyr gått opp med 41 prosent mellom 2013 og 2017 (2).

Sykepleieren i klinikken har som regel blikket rettet mot situasjonen her og nå og i mindre grad mot fremtiden i et globalt perspektiv. Vi gir omsorg i nære møter med pasientens lidelse, og vi handler ut fra en plikt til å gjøre godt og ikke skade, respektere pasientens selvbestemmelse og ivareta rettferdighet.

\section{Sykepleiere har et etisk miljøansvar}

I dagens situasjon med klimautfordringene $b ø r$ sykepleiere la seg berøre av klodens dårlige helse og ta initiativ som bidrar til en bedre tilstand for jorden vår.

\section{«Miljøaspektet må ivaretas i de små hverdagslige handlingene, både privat og profesjonelt.»}

I dag står vi midt i koronavirusets utfordringer, og sparing og miljøhensyn kommer i bakgrunnen. En dag vil vi være tilbake i en tilnærmet normal situasjon, og da må vi være miljøbevisste $\mathrm{i}$ handlingene våre. 
Sykepleierens etiske plikt til å fremme miljøvennlige helsetjenester ligger både i å utdanne seg selv i tillegg til studenter, pasienter og pårørende, og miljøaspektet må ivaretas i de små hverdagslige handlingene, både privat og profesjonelt.

\section{Referanser}

1. Dhillon VS, Kaur D. Green hospital and climate change: their interrelationship and the way forward. Journal of Clinical and Diagnostic Research. 2015;9(12):LEO1-LEO5.

2. Helse Bergen HF, Haukeland universitetssjukehus. Energi- og klimaregnskap 2017. Anskaffelser i helsesektoren. Helse Bergen HF, Haukeland universitetssjukehus; 2018.

3. Laustsen G. Reduce-recycle-reuse: guidelines for promoting perioperative waste management. AORN J. 2007;85(4):717-28.

4. Shaner-McRae H, McRae G, Jas V. Environmentally safe health care agencies: nursing's responsibilities, Nightingale's legacy. Online J Issues Nurs.

Tilgjengelig fra: http://ojin.nursingworld.org/MainMenuCategories/ ANAMarketplace/ANAPeriodicals/OJIN/TableofCo ntents/Volume122007/No2Mayo7/Environmentally SafeHealthCareAgencies.html (nedlastet 19.03.2020).

5. Harris N, Pisa L, Talioaga S, Vezeau T. Hospitals going green - a holistic view of the issue and the critical role of the nurse leader. Holist Nurs Pract. 2009;23(2):101-11. 